\title{
Inside the volcano: Three-dimensional magmatic architecture of a buried shield volcano
}

\author{
Faye Walker $^{1 *}$, Nick Schofield ${ }^{1}$, John Millett ${ }^{1,2}$, Dave Jolley ${ }^{1}$, Simon Holford ${ }^{3}$, Sverre Planke ${ }^{2,4}$, Dougal A. Jerram ${ }^{4,5}$ \\ and Reidun Myklebust ${ }^{6}$ \\ ${ }^{1}$ Geology and Petroleum Geology, University of Aberdeen, Aberdeen AB24 3UE, UK \\ ${ }^{2}$ Volcanic Basin Petroleum Research, Blindernveien 5, N-0361 Oslo, Norway \\ ${ }^{3}$ Australian School of Petroleum, University of Adelaide, Adelaide, South Australia 5000, Australia \\ ${ }^{4}$ Centre for Earth Evolution and Dynamics (CEED), University of Oslo, N-0315 Oslo, Norway \\ 5DougalEARTH Ltd., Solihull B91 3NU, UK \\ 6TGS, Asker N-1386, Norway
}

\begin{abstract}
The nature and growth of magmatic plumbing systems are of fundamental importance to igneous geology. Traditionally, magma chambers have been viewed as rapidly emplaced bodies of molten rock or partially crystallized "magma mush" connected to the surface by a narrow cylindrical conduit (referred to as the "balloon-and-straw" model). Recent data suggest, however, that magma chambers beneath volcanoes are formed incrementally through amalgamation of smaller intrusions. Here we present the first high-resolution threedimensional reconstruction of an ancient volcanic plumbing system as a large laccolithic complex. By integrating seismic reflection and gravity data, we show that the $\sim 200 \mathbf{~ k m}^{3}$ laccolith appears to have formed through partial amalgamation of smaller intrusions. The complex appears to have fed both surface volcanism and an extensive sill network beneath the volcanic edifice. Numerous sills are imaged within the volcanic conduit, indicating that magma stalled at various levels during its ascent. Our results reveal for the first time the entire multicomponent plumbing system within a large ancient shield volcano.
\end{abstract}

\section{INTRODUCTION}

Extensive study of modern shield volcanoes, e.g., in Hawaii and Iceland, has provided detailed understanding of surface processes associated with basaltic volcanism (Moore and Clague, 1992; Valentine and Gregg, 2008; Cashman and Sparks, 2013). However, knowledge of the internal three-dimensional (3-D) structure of volcanic edifices and how this influences the storage and transport of magma within plumbing systems is comparatively poor. This is because these systems cannot be observed directly and are generally studied through incomplete eroded outcrops (e.g., Chambers and Pringle, 2001; Westerman et al., 2004; Emeleus and Bell, 2005; Galland et al., 2018). Such exposures commonly provide a limited view of the inner workings of the volcanic system, with most of the structure remaining buried and inaccessible, and key features, such as the conduit and chamber contacts,

*E-mail: faye.walker@abdn.ac.uk commonly missing. Although careful reconstruction of eroded plutons based on detailed field mapping (e.g., Mattsson et al., 2018) has proven useful, the fundamental limits of surface exposure cannot be circumvented by fieldwork alone. Previous studies have attempted to image magma chambers using seismic tomography (e.g., Bushenkova et al., 2019), and while such data can indicate locations and approximate volumes of large magma bodies, the low spatial resolution (typically several kilometers) means that detailed geometries and melt distributions remain poorly constrained (Sparks et al., 2019). Seismic reflection data (with typical vertical and lateral resolutions of tens of meters) enable visualization of this detail (e.g., Bischoff et al., 2017). However, although intrusive complexes within sedimentary basins (Cartwright and Hansen, 2006; Schofield et al., 2015) and melt lenses beneath active seafloor spreading centers (e.g., Arnulf et al., 2014) have previously been imaged using seismic data, the fossilized plumbing system associated with a large volcanic center and its magma chamber have never been imaged in detail before.

Magma chambers have traditionally been viewed as large, long-lived, geometrically simple bodies of molten rock, which are emplaced rapidly and slowly crystallize to form plutons (Glazner et al., 2004; Annen et al., 2015; Jerram and Bryan, 2018; Sparks et al., 2019). These chambers are typically depicted as being connected to the surface by a vertical cylindrical conduit allowing for movement and eruption of magma, commonly known as the "balloonand-straw" model (i.e., a large balloon-like magma chamber and a narrow straw-like conduit; Jerram and Bryan, 2018). There is little geophysical evidence for large melt-dominated magma chambers in active volcanic areas, however, causing researchers to propose that large magma bodies are transient and that magmatic systems are instead dominated by partially crystalline "magma mush" with small melt fractions (Glazner et al., 2004; Annen et al., 2015; Sparks et al., 2019). An emerging view is that magma chambers are emplaced incrementally via amalgamation of numerous smaller intrusions into a single body, so that at any one time, only a small fraction of the chamber is molten (Glazner et al., 2004; Menand, 2011; Michaut and Jaupart, 2011; Annen et al., 2015; Morgan, 2018).

The focus of this study is the Erlend volcano, a polygenetic shield volcano in the northeastern Faroe-Shetland Basin (Fig. 1), which is now buried by $\sim 1100 \mathrm{~m}$ of sedimentary strata. This is one of numerous volcanoes that erupted along the pre-rift northeastern Atlantic margin (Ritchie et al., 2011, p. 222-228) between ca. 62 and $55 \mathrm{Ma}$. Unlike many ancient volcanoes, it has been drilled at three locations (hydrocarbon

CITATION: Walker, F., et al., 2021, Inside the volcano: Three-dimensional magmatic architecture of a buried shield volcano: Geology, v. 49, p. 243-247, https://doi.org/10.1130/G47941.1 


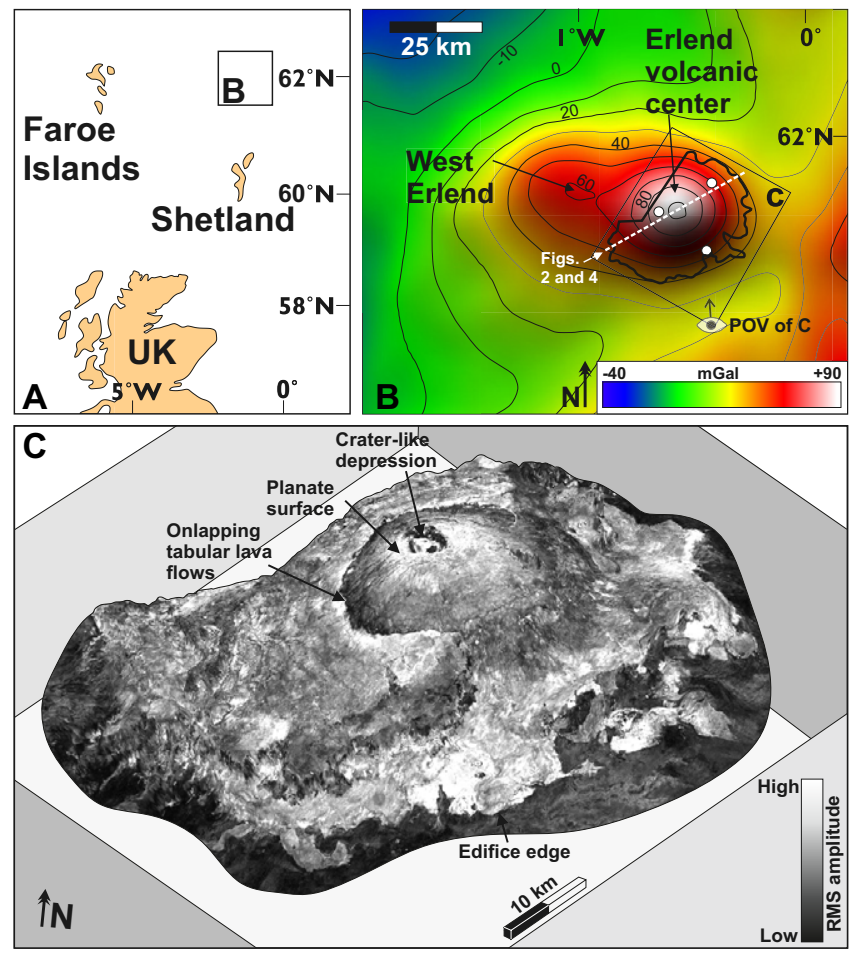

exploration wells 209/03-1 (drilled in 1980 by Mobil North Sea Ltd.), 209/04-1a (drilled in 1985 by North Sea Sun Oil Company Ltd.), and 209/09-1 (drilled in 1979-1980 by the British National Oil Corporation; Fig. 1B), providing good subsurface constraints for seismic interpretation. The wells reveal varying thicknesses of basaltic lava and hyaloclastite interbedded with siltstones and mudstones, underlain by Paleocene and Cretaceous sedimentary rocks containing abundant mafic and felsic intrusions (Kanaris-Sotiriou et al., 1993; Ridd, 1983; Jolley and Bell, 2002).

In this study, we present the first high-resolution 3-D seismic images of a subsurface shield volcano (Erlend; Fig. 1C; Fig. S1 in the Supplemental Material $\left.{ }^{1}\right)$ and its magmatic plumbing system, revealed by careful seismic mapping. The plumbing system comprises a large laccolithic complex that appears to feed hundreds of seismically resolvable, radially distributed sills (similar to examples in the Henry Mountains, Utah, USA; Johnson and Pollard, 1973) and a conduit structure containing numerous stacked sills.

${ }^{1}$ Supplemental Material. Detailed methodology, Video S1 (volcanic edifice and plumbing system in 3-D), and Figures S2-S6. Please visit https://doi .org/10.1130/GEOL.S.12990923 to access the supplemental material, and contact editing @ geosociety.org with any questions.

\section{METHODS}

The first part of this study consisted of detailed seismic interpretation of the Erlend edifice and its plumbing system using a 3-D seismic volume covering an area of $2000 \mathrm{~km}^{2}$. The second part of the study used 2-D gravity modeling to determine the nature and geometry of the laccolithic complex. The gravity response was modeled for three different scenarios and compared to the observed free-air gravity anomaly over the volcano. For further details and explanation, see the Supplemental Material.

\section{STRUCTURE OF THE ERLEND EDIFICE}

The Erlend volcano is an elliptical dome with a diameter of 30-50 km (Fig. 1C). The volcano flanks comprise numerous subaerially erupted compound lava flows that dip radially away from the crest (Fig. 2). The edifice is onlapped on all sides except the eastern side by a package of tabular lava flows originating from a fissure to the west of the volcano. Packages of clinoforms build radially outward at the edifice margins, interpreted as subaqueous hyaloclastite deltas formed due to lava flowing into a body of water.

The volcanic sequence is as much as $\sim 1 \mathrm{~km}$ thick at the crest of the volcano and thins toward its edges (Fig. 2), with an estimated volume of $\sim 400 \mathrm{~km}^{3}$. The crest has been extensively eroded, resulting in a planate surface $\sim 100 \mathrm{~km}^{2}$ in area (Figs. 1C and 2). Extending the preserved flanks of the volcanic edifice upward suggests that the thickness of material removed by erosion may be as much as $\sim 600-700 \mathrm{~m}$ (Fig. 2).

\section{MAGMATIC PLUMBING SYSTEM}

Sedimentary strata beneath the Erlend volcano are heavily intruded, containing $>300$ seismically resolvable igneous intrusions (Figs. 2

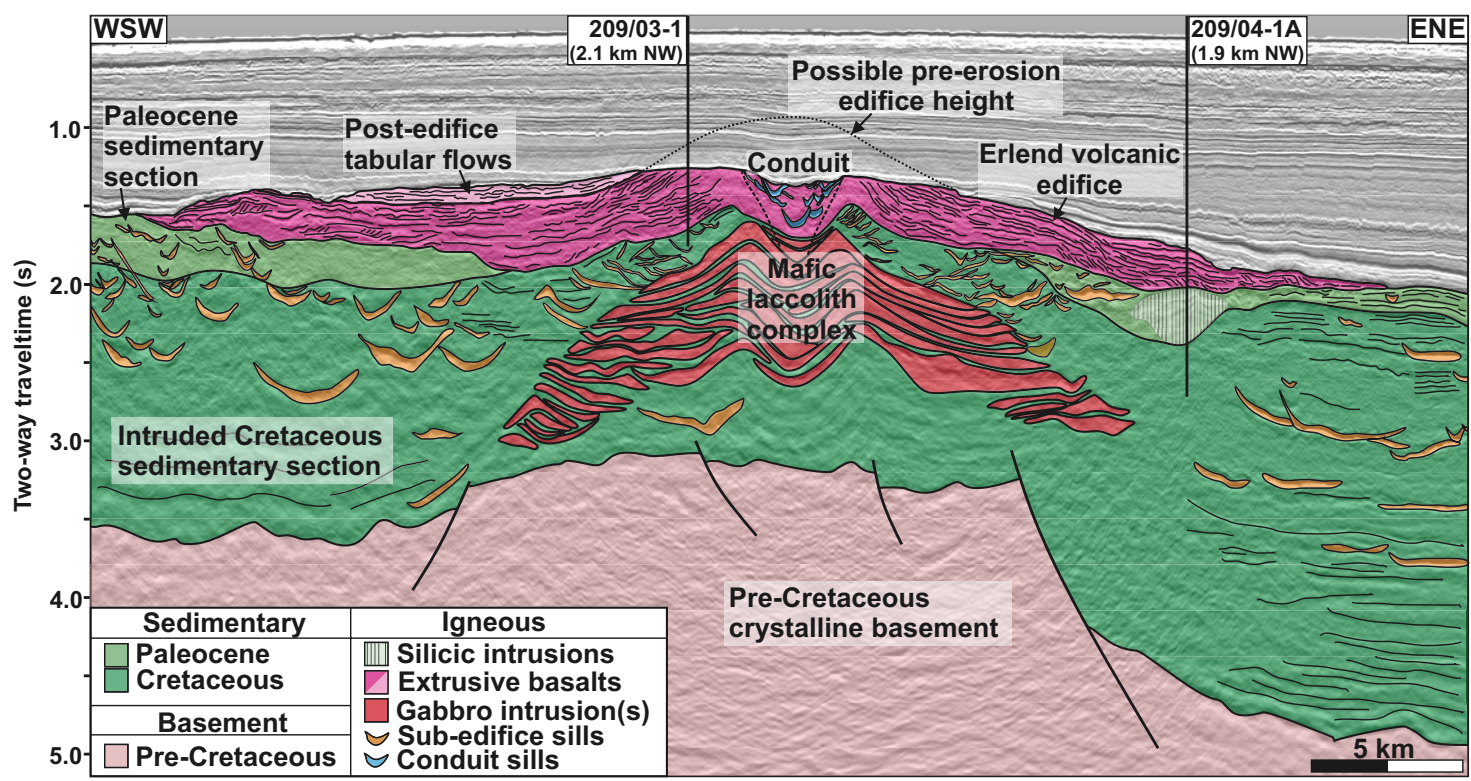

Figure 2. Arbitrary seismic line across the Erlend volcano (Faroe-Shetland Basin) showing extrusive lava flows, volcanic conduit, laccolith complex, and associated sills. Dotted line shows possible edifice height before erosion. Note that wells are offset (distance from line is indicated). Line location is shown in Figure 1B. Uninterpreted line is shown in Figure S2 (see footnote 1). 

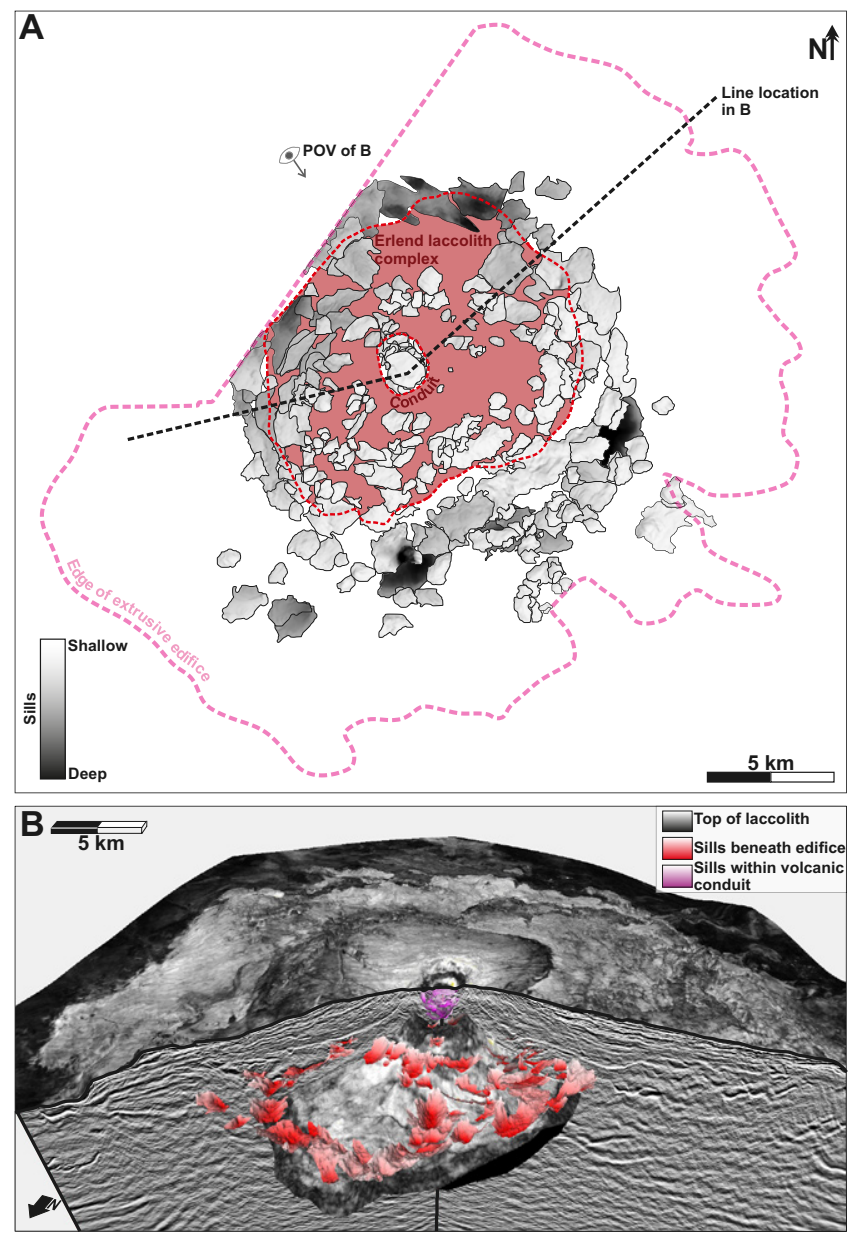

Figure 3. (A) Top-down view of Erlend volcano (Faroe-Shetland Basin) plumbing system, showing all sill intrusions mapped from 3-D seismic reflection data, plus edifice edge, laccolith and conduit. Sills are radially distributed around the conduit and laccolith. POV-point of view. (B) Oblique threedimensional (3-D) view of Erlend volcano created from 3-D seismic reflection data, showing seismic line combined with the top surface of the edifice to the southeast and plumbing system to the northwest. Tops of the edifice and laccolithic complex are displayed using root mean square (RMS) amplitude to improve contrast with colored sills. Red sills are beneath the edifice, many connected to the top of the laccolith. Purple sills are within the conduit. For a complete 3-D view of the plumbing system, see Figure S3 (see footnote 1).

and 3). Intrusions are commonly saucer shaped in 3-D, with diameters ranging from $\sim 150 \mathrm{~m}$ to $>2 \mathrm{~km}$ (Fig. 3A).

Importantly, when mapped out in 3-D, the sills are distributed in a circular fashion around and away from the center of the edifice. Many of these intrusions appear to originate from an inclined $\left(\sim 10^{\circ}\right)$ high-amplitude positive reflection (Fig. 2) that forms a broad domal feature $\sim 15 \mathrm{~km}$ in diameter and $\sim 3 \mathrm{~km}$ high with a volume of $\sim 200 \mathrm{~km}^{3}$, located directly beneath the volcano's crest (Fig. 3B). A second positive high-amplitude reflection occurs $\sim 500-600 \mathrm{~ms}$ two-way traveltime (TWT; $\sim 2 \mathrm{~km}$ ) deeper, which is generally subhorizontal to shallowly dipping (as much as $\sim 6^{\circ}$ ) away from the center of the edifice. Numerous low- to moderateamplitude reflections, which are commonly subhorizontal, are observed between these two reflectors (Fig. 2).

\section{IS THE SUB-EDIFICE DOME A FOSSILIZED MAGMA CHAMBER?}

Although the nature of the domal feature cannot be determined using seismic data alone, its circular geometry combined with regional seismic interpretation (Fig. S4) precludes it being a subvolcanic crustal basement high. High-pass-filtered gravity data and the short fore not be wholly gabbroic, likely incorporating lower-density material (e.g., lenses of country rock). This interpretation is supported by the observation of reflectivity within the plutonic body, indicative of compositional and/or structural heterogeneity.

In Model C, the dome is modeled as a series of stacked partially amalgamated mafic sheet intrusions, separated by fragments of country rock which comprise up to $20 \%$ of the total volume (Fig. 4C). This results in an extremely close match to the observed gravity data, and is our preferred solution.

\section{VOLCANIC CONDUIT FEEDER SYSTEM}

A circular depression $\sim 2 \mathrm{~km}$ in diameter and $\sim 500 \mathrm{~m}$ deep, previously interpreted as a volcanic vent (Gatliff et al., 1984), occurs at the peak of the Erlend volcano (Fig. 1C). Given $\sim 600-700 \mathrm{~m}$ of erosion from the volcano crest, such a vent would have been $>1 \mathrm{~km}$ deep, which seems unlikely given that the edifice itself would have been no more than $\sim 1700 \mathrm{~m}$ thick at its highest point. The observation that the depression does not have a flattened base (Fig. 2) suggests that it may represent part of the volcanic conduit, allowing for movement of magma from the deeper plumbing system to the surface, rather than the remnant of a surficial vent. The formation and geometry of volcanic conduits is poorly understood, but it is typically assumed that magma rises vertically through a system of dikes (Bagnardi et al., 2013; Cashman and Sparks, 2013; Burchardt et al., 2018) that branch out and widen upward at very shallow depths $(<100 \mathrm{~m})$ to form eruptive vents (Keating et al., 2008).

The Erlend conduit fill is seismically chaotic and contains numerous high-amplitude saucershaped reflections (Figs. 2 and 3). These are interpreted as sills intruded into a poorly consolidated volcaniclastic unit and appear to form a stacked network, with clear examples of vertical connectivity between individual intrusions (Fig. 2). This geometry is similar to that of sill complexes identified within crater walls on the volcanic island of Ambrym, Vanuatu (Németh and Cronin, 2008). The sills within the Erlend conduit probably represent the upper part of the volcanic plumbing system, similar to intrusive complexes observed in the cores of exposed eroded volcanoes (e.g., Walker, 1992; Emeleus and Bell, 2005), supporting the interpretation of the circular depression as a volcanic conduit.

\section{DISCUSSION}

Our seismic interpretation and gravity modeling suggest that the intrusive complex situated beneath the Erlend volcano is laccolithic in shape with a volume of $\sim 200 \mathrm{~km}^{3}$, comprising a series of interconnected amalgamated intrusions, similar to a "Christmas tree" laccolith 

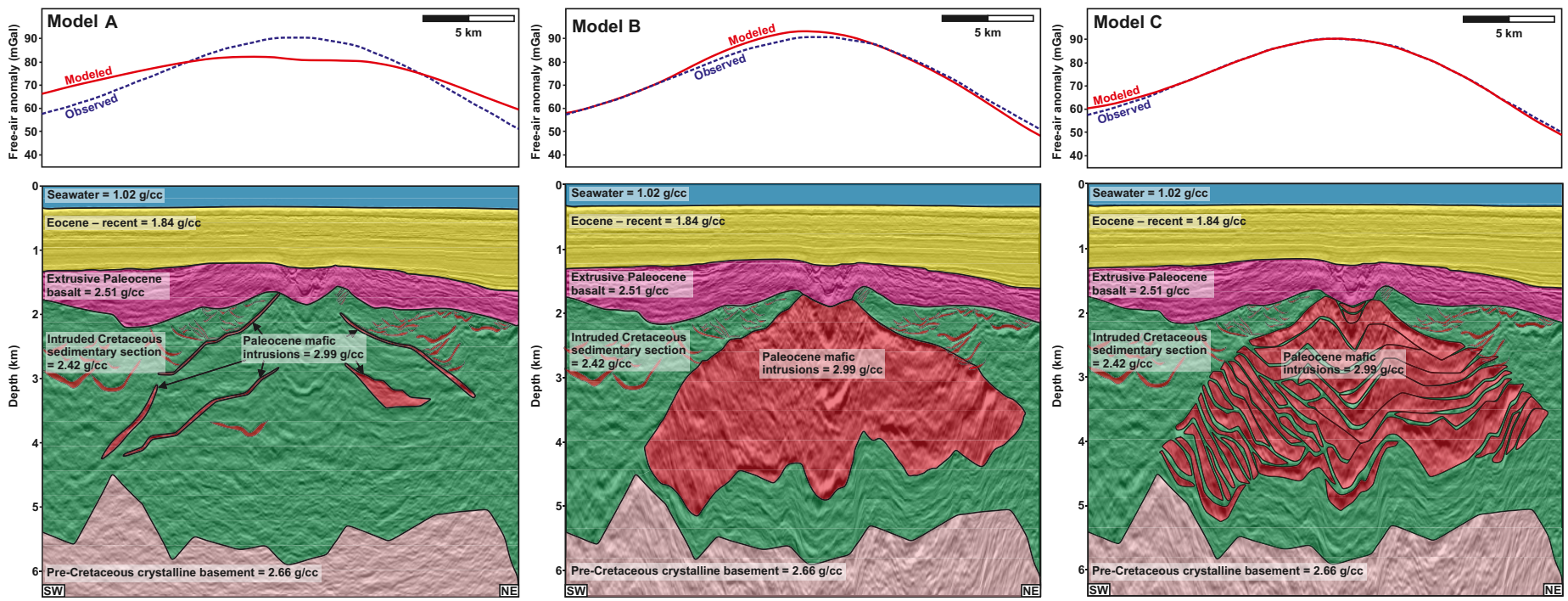

Figure 4. Comparison of modeled gravity with observed free-air anomaly at Erlend volcano (Faroe-Shetland Basin). Lower panels show model parameters overlaid on depth-converted seismic line. (A) Plumbing system is modeled as a series of ring dikes. Modeled gravity anomaly is much lower than the observed anomaly. (B) The plumbing system is modeled as a solid gabbro body. Modeled anomaly is too high over the southwestern part of the system, but otherwise shows a close match to the observed anomaly. (C) The plumbing system is modeled as numerous partially amalgamated intrusions. Modeled and observed gravity anomalies are closely matched. Note: Different geometry of preCretaceous basement between Figures 2 and 4 is due to time-depth conversion.

complex (e.g., Elba Island, Italy; Westerman et al., 2004). Gravity model C (Fig. 4C) plus seismic reflectivity throughout the laccolith suggest that in much of the complex, individual intrusions did not fully coalesce, leaving them separated by lenses of country rock. This interpretation is supported by recent petrological and geochronological data and theoretical modeling pertaining to the formation of crustal plutons, which imply that many large igneous bodies are emplaced incrementally (Glazner et al., 2004; Menand, 2011; Michaut and Jaupart, 2011).

The presence of numerous interconnected sills within the volcanic conduit indicates that sills may play a key role in the ascent and eruption of magma, in addition to dikes as observed in the field (e.g., Keating et al., 2008). It is clear that the common assumption when modeling volcanic eruptions that magma rises up a vertical cylindrical conduit to the surface (Gonnermann and Manga, 2012; Cashman and Sparks, 2013) is likely an extreme oversimplification, and that magma pathways can be far more complex, incorporating both sills and dikes (e.g., Bagnardi et al., 2013).

An overriding observation from our seismic data is that the subvolcanic plumbing system of Erlend is complex and contrasts markedly with the classic "balloon-and-straw" model. Instead, Erlend consists of three distinct magmatic domains: a laccolithic central complex, radiating sills fed away from that complex, and a separate sill network within the volcanic conduit. Although these systems are interconnected, it is likely that there was significant variability in magma properties between the domains due to changes in, e.g., temperature, flow rate, and fractionation. The radiating sill network appears to have been fed from various levels of the laccolithic complex and may therefore have tapped into different magma batches within the evolving magma bodies (Jackson et al., 2018), which may explain the coexistence of mafic and felsic intrusions within the Erlend wells. Similarly, the intra-conduit sills and much of the extrusive lava appear to have been fed from the uppermost part of the laccolithic complex, again sampling another distinct part of the magmatic system. Outcrop- or drilling-based petrological and geochemical studies of similar plumbing systems, which commonly sample only a tiny part of one of these domains, are therefore unlikely to be representative of the entire system. Therefore, while it is important to note that detailed geochronological and geochemical work has given substantial insights into magmatic plumbing systems (e.g., Glazner et al., 2004; Michaut and Jaupart, 2011), such methods are commonly indirect and commonly spatially poorly representative. Our work highlights the substantial challenges in using such methods in isolation to characterize the spatial and temporal evolution of an entire volcanic system when they may have only sampled one subset of a complex subsurface magmatic system.

\section{ACKNOWLEDGMENTS}

Funding from the U.K. Natural Environment Research Council (NERC) (Oil and Gas Centre for Doctoral training) and the British Geological Survey is gratefully acknowledged. Jerram and Planke are partly funded by the Research Council of Norway Centre of Excellence funding scheme (project 223272). TGS (www.tgs.com) is thanked for providing seismic data to the University of Aberdeen, UK. Seismic interpretation was undertaken using Schlumberger Petrel software and gravity modeling using ARK CLS XField software. Thanks go to Steffi Burchardt, Eric
Horsman, and Christian Eide for constructive reviews that greatly improved the manuscript.

\section{REFERENCES CITED}

Annen, C., Blundy, J.D., Leuthold, J., and Sparks, R.S.J., 2015, Construction and evolution of igneous bodies: Towards an integrated perspective of crustal magmatism: Lithos, v. 230, p. 206-221, https://doi.org/10.1016/j.lithos.2015.05.008.

Arnulf, A.F., Harding, A.J., Kent, G.M., Carbotte, S.M., Canales, J.P., and Nedimovi, M.R., 2014, Anatomy of an active submarine volcano: Geology, v. 43, p. 655-658, https://doi.org/10.1130/ G35629.1.

Bagnardi, M., Amelung, F., and Poland, M.P., 2013, A new model for the growth of basaltic shields based on deformation of Fernandina volcano, Galápagos Islands: Earth and Planetary Science Letters, v. 377-378, p. 358-366, https:// doi.org/10.1016/j.epsl.2013.07.016

Bischoff, A.P., Nicol, A., and Beggs, M., 2017, Stratigraphy of architectural elements in a buried volcanic system and implications for hydrocarbon exploration: Interpretation (Tulsa), v. 5, p. SK141-SK159, https://doi .org/10.1190/INT-2016-0201.1.

Burchardt, S., Walter, T.R., and Tuffen, H., 2018, Growth of a volcanic edifice through plumbing system processes-Volcanic rift zones, magmatic sheet-intrusion swarms and long-lived conduits, in Burchardt, S., ed., Volcanic and Igneous Plumbing Systems: Understanding Magma Transport, Storage, and Evolution in the Earth's Crust: Amsterdam, Elsevier, p. 89-112, https:// doi.org/10.1016/B978-0-12-809749-6.00004-2.

Bushenkova, N., Koulakov, I., Senyukov, S., Gordeev, E.I., Huang, H.-H., El Khrepy, S., and Al Arifi, N., 2019, Tomographic images of magma chambers beneath the Avacha and Koryaksky volcanoes in Kamchatka: Journal of Geophysical Research: Solid Earth, v. 124, p. 9694-9713, https://doi.org/10.1029/2019JB017952.

Cartwright, J., and Hansen, D.M., 2006, Magma transport through the crust via interconnected sill complexes: Geology, v. 34, p. 929-932, https:// doi.org/10.1130/G22758A.1. 
Cashman, K.V., and Sparks, R.S.J., 2013, How volcanoes work: A 25 year perspective: Geological Society of America Bulletin, v. 125, p. 664-690, https://doi.org/10.1130/B30720.1.

Chambers, L.M., and Pringle, M.S., 2001, Age and duration of activity at the Isle of Mull Tertiary igneous centre, Scotland, and confirmation of the existence of subchrons during Anomaly 26r: Earth and Planetary Science Letters, v. 193, p. 333-345, https://doi.org/10.1016/ S0012-821X(01)00499-X.

Emeleus, C.H., and Bell, B.R., 2005, The Palaeogene Volcanic Districts of Scotland (fourth edition): Nottingham, British Geological Survey, 214 p.

Galland, O., et al., 2018, Storage and transport of magma in the layered crust-Formation of sills and related flat-lying intrusions, in Burchardt, S., ed., Volcanic and Igneous Plumbing Systems: Understanding Magma Transport, Storage, and Evolution in the Earth's Crust: Amsterdam, Elsevier, p. 113-138, https://doi.org/10.1016/B978-012-809749-6.00005-4.

Gatliff, R.W., Hitchen, K., Ritchie, J.D., and Smythe, D.K., 1984, Internal structure of the Erlend Tertiary volcanic complex, north of Shetland, revealed by seismic reflection: Journal of the Geological Society, v. 141, p. 555-562, https:// doi.org/10.1144/gsjgs.141.3.0555.

Glazner, A.F., Bartley, J.M., Coleman, D.S., Gray, W., and Taylor, R.Z., 2004, Are plutons assembled over millions of years by amalgamation from small magma chambers?: GSA Today, v. 14, no. 4-5, p. 4-11, https://doi.org/10.1130/10525173(2004)014<0004:APAOMO>2.0.CO;2.

Gonnermann, H.M., and Manga, M., 2012, Dynamics of magma ascent in the volcanic conduit, in Fagents, S.A., et al., eds., Modeling Volcanic Processes: The Physics and Mathematics of Volcanism: Cambridge, UK, Cambridge University Press, p. 55-84, https://doi.org/10.1017/ CBO9781139021562.004.

Jackson, M.D., Blundy, J., and Sparks, R.S.J., 2018, Chemical differentiation, cold storage and remobilization of magma in the Earth's crust: Nature, v. 564, p. 405-409, https://doi .org/10.1038/s41586-018-0746-2.

Jerram, D.A., and Bryan, S.E., 2018, Plumbing systems of shallow level intrusive complexes, in Breitkreuz, C., and Rocchi, S., eds., Physical Geology of Shallow Magmatic Systems: Dykes, Sills and Laccoliths: Cham, Switzerland, Springer International Publishing, p. 39-60, https://doi .org/10.1007/11157_2015_8.

Johnson, A.M., and Pollard, D.D., 1973, Mechanics of growth of some laccolithic intrusions in the Henry mountains, Utah, I: Field observations,
Gilbert's model, physical properties and flow of the magma: Tectonophysics, v. 18, p. 261-309, https://doi.org/10.1016/0040-1951(73)90050-4.

Johnson, S.E., Schmidt, K.L., and Tate, M.C., 2002, Ring complexes in the Peninsular Ranges Batholith, Mexico and the USA: Magma plumbing systems in the middle and upper crust: Lithos, v. 61, p. 187-208, https://doi .org/10.1016/S0024-4937(02)00079-8.

Jolley, D.W., and Bell, B.R., 2002, Genesis and age of the Erlend Volcano, NE Atlantic Margin, in Jolley, D.W. and Bell, B.R. eds., The North Atlantic Igneous Province: Stratigraphy, Tectonic, Volcanic and Magmatic Processes: Geological Society of London Special Publication 197, p. 95-109, https://doi.org/10.1144/GSL.SP.2002.197.01.05.

Kanaris-Sotiriou, R., Morton, A.C., and Taylor, P.N., 1993, Palaeogene peraluminous magmatism, crustal melting and continental breakup: The Erlend complex, Faeroe-Shetland Basin, NE Atlantic: Journal of the Geological Society, v. 150, p. 903-914, https://doi.org/10.1144/ gsjgs.150.5.0903.

Keating, G.N., Valentine, G.A., Krier, D.J., and Perry, F.V., 2008, Shallow plumbing systems for smallvolume basaltic volcanoes: Bulletin of Volcanology, v. 70, p. 563-582, https://doi.org/10.1007/ s00445-007-0154-1.

Lowrie, W., 2007, Fundamentals of Geophysics (second edition): Cambridge, UK, Cambridge University Press, 381 p., https://doi.org/10.1017/ CBO9780511807107.

Mattsson, T., Burchardt, S., Almqvist, B.S.G., and Ronchin, E., 2018, Syn-emplacement fracturing in the Sandfell laccolith, eastern Iceland-Implications for rhyolite intrusion growth and volcanic hazards: Frontiers of Earth Science, v. 6, 5, https://doi.org/10.3389/feart.2018.00005.

Menand, T., 2011, Physical controls and depth of emplacement of igneous bodies: A review: Tectonophysics, v. 500, p. 11-19, https://doi .org/10.1016/j.tecto.2009.10.016.

Michaut, C., and Jaupart, C., 2011, Two models for the formation of magma reservoirs by small increments: Tectonophysics, v. 500, p. 34-49, https:// doi.org/10.1016/j.tecto.2009.08.019.

Moore, J.G., and Clague, D.A., 1992, Volcano growth and evolution of the island of Hawaii: Geological Society of America Bulletin, v. 104, p. 14711484, https://doi.org/10.1130/00167606(1992)104<1471:VGAEOT>2.3.CO;2.

Morgan, S., 2018, Pascal's principle, a simple model to explain the emplacement of laccoliths and some mid-crustal plutons, in Burchardt, S., ed., Volcanic and Igneous Plumbing Systems: Understanding Magma Transport, Storage, and Evolution in the Earth's Crust: Amsterdam, Elsevier, p. 139165, https://doi.org/10.1016/B978-0-12-8097496.00006-6.

Németh, K., and Cronin, S.J., 2008, Volcanic craters, pit craters and high-level magma-feeding systems of a mafic island-arc volcano: Ambrym, Vanuatu, South Pacific, in Thomson, K., and Petford, N., eds., Structure and Emplacement of High-Level Magmatic Systems: Geological Society of London Special Publication 302, p. 87-102, https:// doi.org/10.1144/sp302.6.

Ridd, M.F., 1983, Aspects of the Tertiary geology of the Faeroe-Shetland Channel, in Bott, M.H.P., et al., eds., Structure and Development of the Greenland-Scotland Ridge: New York, Plenum Press, p. 91-108, https://doi.org/10.1007/978-14613-3485-9_6.

Ritchie, J.D., Ziska, H., Johnson, H., and Evans, D., eds., 2011, Geology of the Faroe-Shetland Basin and adjacent areas: British Geological Survey Research Report RR/10/01 and Jarðfeingi Research Report RR/10/01, 317 p., http://nora .nerc.ac.uk/13396/.

Schofield, N., et al., 2015, Regional magma plumbing and emplacement mechanisms of the Faroe-Shetland Sill Complex: Implications for magma transport and petroleum systems within sedimentary basins: Basin Research, v. 29, p. 41-63, https:// doi.org/10.1111/bre.12164.

Sparks, R.S.J., Annen, C., Blundy, J.D., Cashman, K.V., Rust, A.C., and Jackson, M.D., 2019, Formation and dynamics of magma reservoirs: Philosophical Transactions of the Royal Society A: Mathematical, Physical, and Engineering Sciences, v. 377, 20180019, https://doi.org/10.1098/ rsta.2018.0019.

Valentine, G.A., and Gregg, T.K.P., 2008, Continental basaltic volcanoes-Processes and problems: Journal of Volcanology and Geothermal Research, v. 177 , p. $857-873$, https://doi .org/10.1016/j.jvolgeores.2008.01.050.

Walker, G.P.L., 1992, "Coherent intrusion complexes" in large basaltic volcanoes: A new structural model: Journal of Volcanology and Geothermal Research, v. 50, p. 41-54, https://doi .org/10.1016/0377-0273(92)90036-D.

Westerman, D.S., Dini, A., Innocenti, F., and Rocchi, S., 2004, Rise and fall of a nested Christmas-tree laccolith complex, Elba Island, Italy, in Breitkreuz C., and Petford, N., eds., Physical Geology of High-Level Magmatic Systems: Geological Society of London Special Publication 234, p. 195-213, https://doi.org/10.1144/GSL. SP.2004.234.01.12.

Printed in USA 